\title{
THE EFFECT OF EXPERIMENTAL CONDITIONS, THE SAMPLE SIZE AND SESSION DURATION ON RESTING-STATE SUBJECTIVE EXPERIENCE
}

\author{
G.V. PORTNOVA ${ }^{\mathrm{a}}$, A.O. TETEREVA ${ }^{\mathrm{a}, \mathrm{b}}$, A.M. IVANITSKY ${ }^{\mathrm{a}}$, \\ O.V. MARTYNOVA ${ }^{\mathrm{a}, \mathrm{b}}$, K.M. LIAUKOVICH ${ }^{\mathrm{a}}$
}

${ }^{a}$ Institute of Higher Nervous Activity and Neurophysiology of the Russian Academy of Sciences, 5 a Butlerova Str., Moscow, 1174855, Russian Federation

${ }^{b}$ National Research University Higher School of Economics, 20 Myasnitskaya Str., Moscow, 101000, Russian Federation

\begin{abstract}
Our research aims to study the difference in resting-state during EEG and fMRI experimental conditions, each of which has its own peculiarities. Therefore, we conducted EEG and fMRI experiments very close in terms of conditions, during which 108 and 109 healthy participants, respectively, were recorded at rest for ten minutes. Subjective content of conscious during resting-state was assessed using the Amsterdam Resting-State Questionnaire (ARSQ) 2.0. To approve the 10-factor structure of the questionnaire in both groups we used the method of confirmatory factor analysis, the differences between groups were assessed using the Mann-Whitney $\mathrm{U}$ test. In general, it was found that responses towards the Amsterdam Resting-State Questionnaire 2.0. were similar in both groups. However, during resting-state the EEG group had larger scores for Comfort, Sleepiness and Visual Thought, while the fMRI group had larger scores for Health Concerns. The gender differences were similar in both groups for the dimension of Verbal Thoughts, which was significantly higher in females. Thus, our findings imply a substantial effect of the experimental environment difference for fMRI and EEG on subjective thoughts and feelings during resting-state experience, even when the experimental conditions are similar. That should be taken into account when planning a research experiment and analyzing data.
\end{abstract}

Keywords: Amsterdam Resting-State Questionnaire, resting-state, fMRI, EEG, mind wandering.

\section{Introduction}

The content of a person's consciousness consists of a sequence of internally experienced states that form a single stream of consciousness, even during quiet

The collection and analysis of data from respondents participating in the EEG study was carried out within the state assignment of Ministry of Education and Science of the Russian Federation for 2019-2021 (No. AAAA-A17-117092040004-0). Data collection from respondents participating in the fMRI study, as well as general data analysis, were supported by the Russian Science Foundation, grant RSF 16-15-00300. 
wakefulness (James, 1890; Killingsworth \& Gilbert, 2010). This content, reflected in fluctuations of brain activity, includes inner speech, a sequence of alternating visual images, sounds and melodies, and feelings that accompany these experiences (Lee, Smyser, \& Shimony, 2013; Glover, 2011). Until recently, psychological and neurophysiological studies of the content of human consciousness as a rule examined activation of the brain in response to the presentation of stimuli or tasks. Thus, the reactivity of the brain has been explored, rather than its activity. Indeed, it was not until recently that neuroimaging could confirm the existence of stable and structured brain activation in a resting-state (Raichle et al., 2001; Fox et al., 2005; Damoiseaux et al., 2006; Sojoudi \& Goodyear, 2016). It has been suggested that this neural activity maintains both physiological functions (Krug, Salzman, \& Waddell, 2015) and consciousness (Fenigstein, 1987; Heine et al., 2012; Stoffers et al., 2015).

Electroencephalography (EEG) and magnetoencephalography (MEG) revealed stable frequency patterns but variable topography of spectral power distribution among healthy participants (Cantero, Atienza, \& Salas, 2002); functional magnetic resonance imaging (fMRI) allowed the identification of a stable neural activity in specific brain regions (resting-state networks) (Raichle et al., 2001). Accumulated findings on EEG and fMRI signatures of RSNs initiated a search for correlates of the observed background brain activity with the content of consciousness during mind wandering.

Several psychological tests were designed to qualitatively assess a cognitive state at rest. One such is the Amsterdam Resting-State Questionnaire (ARSQ) (Diaz et al., 2013; Diaz et al., 2014), which offers a qualitative and quantitative assessment of thoughts and feelings during a five-minute eyes-closed resting session (Diaz et al., 2013). The questionnaire utilized retrospective self-report to estimate the personal conscious experience according to the ten-dimension model (Diaz et al., 2014). Except for the ARSQ, several questionnaires have been designed to evaluate the content of consciousness at rest. One of them is the New York Cognitive Questionnaire (NYC-Q) (Gorgolewski et al., 2014), which is an improved and revised version of the Dundee Stress State Questionnaire (DSSQ) (Matthews et al., 2002). NYC-Q organizes mind wandering into categories of content (future, past, positive, negative, social) and form (words, images, specificity). However, the ARSQ has been tested and standardized using the most significant number of respondents. The recently extended 54-item ARSQ 2.0 was completed on-line by 993 participants (Diaz et al., 2014). An fMRI study showed that ARSQ scores correlated with patterns of RSNs in 106 participants (Stoffers et al., 2015). In addition to the qualitative differences between EEG and fMRI approaches to reflect neural correlates, the EEG and MRI experimental procedures may peculiarly modulate the cognitive state at rest and consequently effect answers to retrospective questionnaires. The original study of ARSQ 1.0 (Diaz et al., 2013) compared data from EEG $(n=89)$ and fMRI groups $(n=68$ with extensive sample data $(n=813)$ of ARSQ gathered within a natural environment). A direct comparison of factors showed a significant variability of responses to the ARSQ in home and experimental conditions. 
In the current study we further clarify the question of the variability of psychometric data in the resting-state cognition obtained using the newer version of ARSQ 2.0. As in the case of the original study of ARSQ 1.0 (Diaz et al., 2013), we aimed to reveal whether the experiential environment may cause a substantial impact on resting-state cognition reflected in subjective assessment by ARSQ 2.0. For this purpose, we compared the ARSQ 2.0 scores obtained from 109 participants after EEG recordings and from 108 participants of fMRI scanning sessions during resting-state condition, which preceded different active tasks. We focused at differences in the ARSQ factor isolation between the EEG and fMRI groups as well as at their possible variance with previous ARSQ 2.0 data obtained within a natural environment (Diaz et al., 2014).

Additionally, we investigated the impact of session duration, as we used the questionaries' data collected after a 10 minute session (unlike in the original study of Diaz et al. $(2013,2014)$ where the resting-state sessions last 5 minutes). This task was due to the choice to conduct fMRI scanning for $10 \mathrm{~min}$. Most current studies of resting-state using fMRI acquire more than 6 min of fMRI data. This duration is based on findings implying from this amount of data that the strength of functional connectivity is stable (van Dijk et al., 2010; Lee et al., 2013; Mantini et al., 2007).The following research also showed that the reliability and similarity of fMRI data could be significantly improved by increasing the scan lengths from 5 min up to 13 min during resting-state (Birn et al., 2013).

Finally, we addressed the issue of a reliable sample size to correlate with the 10factor model of ARSQ 2.0. The usual sample size for task-based fMRI studies is limited to 25-30 subjects. For clinical use, the best option is to develop a psychometric instrument showing substantial results at an individual level, which provides a correlation with individual neuroimaging data. The strong correlations of ARSQ scores and neuromarkers, such as fMRI and EEG, were shown only for a large number of subjects (Stoffers et al., 2015) or a large number of observations (223 trials in 13 subjects in the sleep study of Diaz et al., 2016). In the recent study of EEG and fMRI correlates of resting-state activity we also revealed an association between the EEG fractal dimension for the band of $2-10 \mathrm{~Hz}$ and the ARSQ factor Health concern. However, in the group of 25 healthy participants the correlation of ARSQ with fMRI data did not pass a correction for multiple comparisons (Portnova et al., 2018). The ARSQ is proposed as a psychometric measure to assess resting-state cognition, as it shows a stable covariance structure between factors, and according to the ARSQ authors' opinion, it appears to reflect stable subject characteristics associated with traits or health status (Diaz et al., 2013). However, if even group ARSQ cross-correlation patterns differ substantially depending on the sample size due to individual variability, could we rely on the retrospective questionnaire such as ARSQ in cases of less subject data? To clarify this question we also tested a correlation and covariation structure along with differences in mean scores of ARSQ 2.0 factors at the half and quarter the reference data sets of the EEG and fMRI groups. 


\section{Materials and methods}

\section{Amsterdam Resting-State Questionnaire}

The Russian-language version of the ARSQ 2.0 was requested and received by e-mail from the ARSQ developers, along with instructions on how to perform the test. As we did not find any published articles regarding the validation of the Russian version of the ARSQ, we adjusted some statements in translation to better convey their intended meanings.

\section{Participants}

We used ARSQ 2.0 data collected from 217 native Russian speakers (Table 1) who participated in different studies in the last three years. Among them, 109 healthy volunteers (61 females, age 23.36 \pm 3.2 ) completed the ARSQ 2.0 after a 10-min resting-state session with simultaneous EEG registration, and 108 healthy volunteers (50 females, age 24.95 \pm 4.1 ) completed the questionnaire after a 10 -min resting-state session during fMRI scanning. All participants were students of higher education institutions at the undergraduate or graduate levels and were recruited via student networks. Before the study, volunteers were interviewed to screen for neurological or mental deficits, pain conditions, and medications. Participants were asked not to drink beverages containing alcohol more than 48 hours before the study, and coffee and tea more than 12 hours before as these substances could affect data collection. All participants provided a written informed consent before each study. All studies were conducted in accordance with the Helsinki Declaration, and the study protocol was approved by the Ethics Department of the Institute of Higher Nervous Activity and Neurophysiology of RAS.

Analysis of respondent answers to Russian ARSQ 2.0 and comparison with data from the original ARSQ 2.0

To keep results compatible with Diaz et al.'s (2014) data, both datasets (EEG and fMRI groups) were filtered based on (1) reported interruption, (2) low motivation (rating of "disagree" or lower), (3) low ability to remember thoughts/feelings (rating of "disagree" or lower), (4) reported inability to recall resting-state cognition (rating below "agree”), (5) not having eyes closed (rating below "agree"), and (6) exhibiting extreme responses on the majority of items. Data of 217 participants included in this study passed through this selection procedure.

Participant responses to 30 main (non-validating) questions were summed up according to a model containing 10 factor measurements implemented by Diaz et al. (2014) in the ARSQ 2.0: (1) Discontinuity of Mind, (2) Theory of Mind, (3) Self, (4) Planning, (5) Sleepiness, (6) Comfort, (7) Somatic Awareness, (8) Health Concerns, (9) Visual Thought, and (10) Verbal Thought. Each answer was equated to a certain number of points: -1 (completely disagree), -2 (disagree), $+/-3$ (unsure - neither agree nor disagree), +4 (agree), and ++5 (completely agree). 


\section{Procedure}

In the study of Diaz et al. $(2013,2014)$ respondents were sitting for 5 minutes duration with instructions to relax and keep their eyes closed and then answer the ARSQ. In our study participants of EEG and fMRI acquisition lay supine for 10 min with similar instructions. The resting-state session preceded the active tasks in all experimental paradigms. Immediately after the resting-state sessions participants were asked to fill out the computer-based ARSQ 2.0 in the separate room. Figure 1 illustrates the experimental procedures for fMRI and EEG conditions.

Before the resting-state session, EEG electrodes were attached to participants of the EEG group $(n=109)$, who were then asked to lay supine on a bed in an acoustically and electrically shielded chamber with the light off. Participants spent $10 \mathrm{~min}$ in this chamber after being instructed to close their eyes, lie still, and try not to move, sleep, or purposefully think about anything. At the end of the restingstate session, subjects were taken out of the scanner and led to another room where they were asked to fill out the questionnaire on a computer. After completing the questionnaire, EEG recording continued; EEG results are not considered in this article.

The fMRI group $(n=108)$ completed the questionnaire after a resting-state session with fMRI scanning. Before the resting-state acquisition, participants of the fMRI group for 5 minutes also had scanning of sagittal brain anatomy. Similar to the EEG recording conditions, subjects lay in a supine position in the MRI scanner with the light off. Through the microphone subjects were instructed to close their eyes and try not to move, sleep, or purposefully think about anything for $10 \mathrm{~min}$. The heart rate and recursive estimation of respiratory motion were registered during MRI to exclude the episodes of sleep. At the end of the resting-state session subjects were taken out of the scanner and led to another room where they were asked to fill out the questionnaire on a computer. There were no time limits for completing the questionnaire imposed on either experimental group.

The Block-Scheme of the EEG And fMRI Experimental Studies

Figure 1

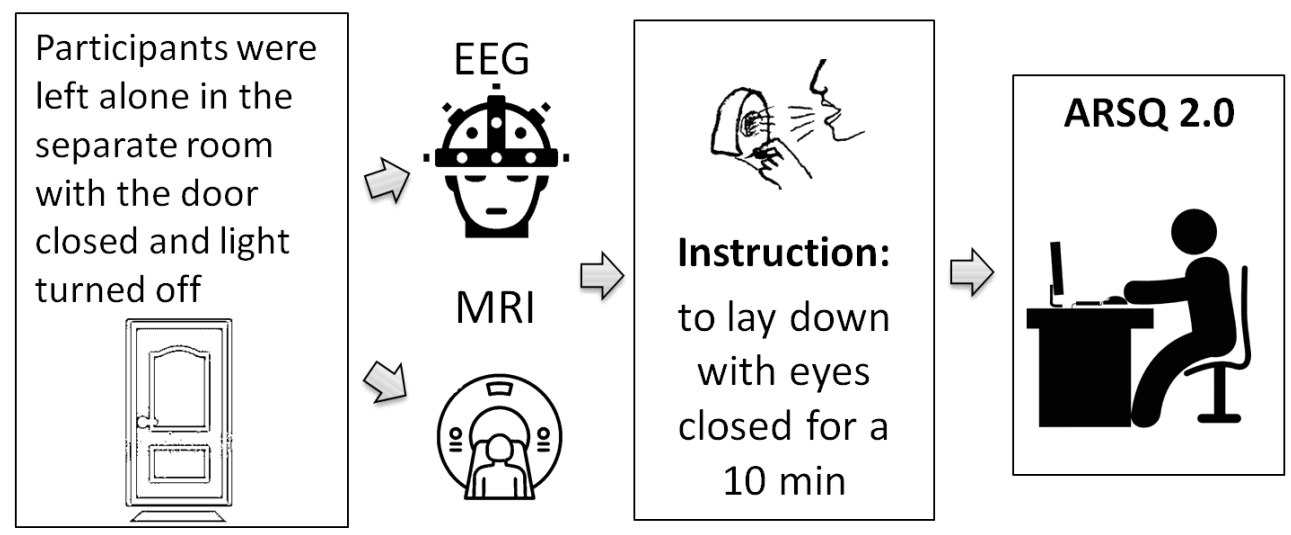




\section{Data analysis}

Confirmatory factor analyses were conducted to support the 10-factor structure implemented following the previous approbation of the ARSQ 2.0 (Diaz et al., 2014). The 10-factor model was subjected to a maximum-likelihood confirmatory factor analysis. First, the analysis was conducted on the whole sample $(\mathrm{N}=217)$ and replicated 100 times for $75 \%$ of data. Second, a multigroup confirmatory factorial analysis was used to assess measurement invariance concerning the experimental paradigm as well as across the fMRI and EEG groups. Cross-correlation analysis between ARSQ factors was performed separately for the fMRI and EEG groups; group differences between factors were again analyzed using the Mann-Whitney test.

Confirmatory factor analyses, correlation analysis, and other non-parametric statistics were performed via Statistica software (Statistica 10, StatSoft Quest Software Inc., Tulsa, OK, USA).

Correlation between factors, as well as with age, was analyzed using Spearman's correlation analysis $(p<0.05)$. The differences in responses between the fMRI and EEG groups and between men and women were assessed using the Mann-Whitney test $(p<0.05)$. Factorial ANOVA tested mixed Group and Gender effects. Cross-correlation analysis between ARSQ factors was performed separately for the fMRI and EEG groups; group differences between factors were again analyzed using the Mann-Whitney test. Correction for multiple comparisons, where applicable, was performed using false discovery rate $p<0.05$ (Benjamini \& Hochberg, 1995). Correlation analysis and other non-parametric statistical tests were performed via Statistica software (Statistica 10, StatSoft Quest Software Inc., Tulsa, OK, USA).

\section{Results}

\section{Comparison of Between-Factor Correlation with Original ARSQ 2.0 Data}

In initial approbation of the ARSQ 2.0 (Diaz et al., 2014), the scores of Discontinuity of Mind positively correlated with scores for Theory of Mind, Planning, and Self. In the current study, we found a similar correlation in the fMRI group. However, no similar correlation was found in the EEG group (Figure 2). The values of the Comfort dimension were inversely correlated with the values of Discontinuity of Mind and Theory of Mind (Ibid.); in the current study no similar correlation was observed. Additionally, while an inverse correlation between Comfort and Health Concerns was found among Dutch-speaking respondents (Ibid.), a similar correlation was found only for the fMRI group in the present study.

\section{Differences in factor scores between EEG and fMRI groups and between genders}

Significant between-group differences were found for the dimensions of Theory of Mind, Sleepiness, Comfort, Health Concern and Visual Thought: the EEG group 


\section{Factorial Correlation Mean Scores}

Figure 2
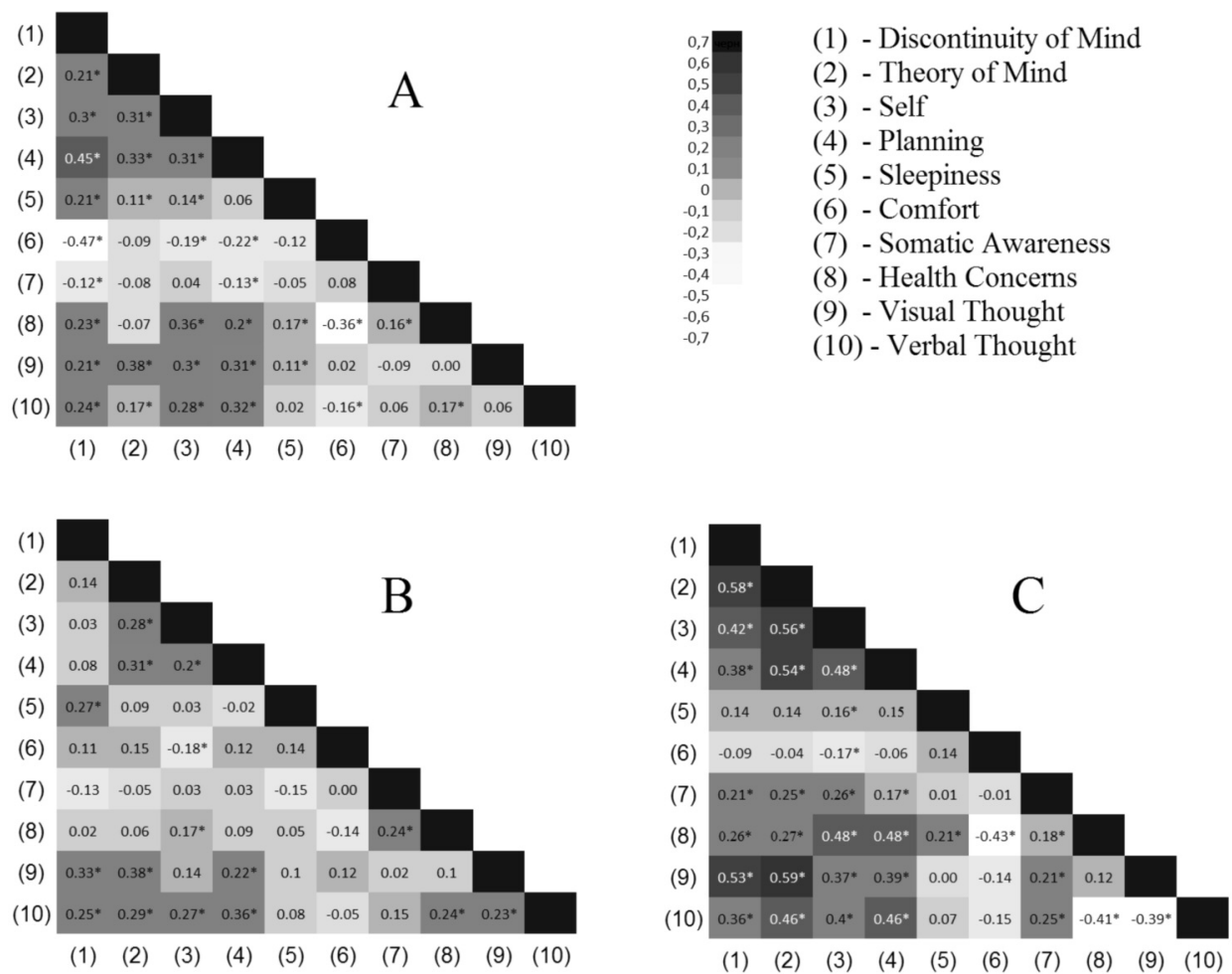

Note. Questionnaire factors: (1) Discontinuity of Mind, (2) Theory of Mind, (3) Self, (4) Planning, (5) Sleepiness, (6) Comfort, (7) Somatic Awareness, (8) Health Concerns, (9) Visual Thought, and (10) Verbal Thought. A represents the data of Diaz et al. (2014) (Copyright (c) 2014 Diaz, Van der Sluis, Benjamins, Stoffers, Hardstone, Mansvelder, Van Someren, and LinkenkaerHansen), B represents the EEG group, and C represents the fMRI group. Shades of colour ranging from blue to red correspond to the values of the correlation coefficient. The symbol * indicates a significant correlation $(p<.05)$

had larger scores for Theory of Mind $(\mathrm{z}=-3.4, p=1 \mathrm{e}-06)$, Sleepiness $(\mathrm{z}=-4.85$, $p=1 \mathrm{e}-06)$, Comfort $(z=-8.11, p=1 \mathrm{e}-06)$ and Visual Thought $(\mathrm{z}=-3.59, p=1 \mathrm{e}-$ 06 ) compared with the fMRI group (Figure 2). The fMRI group had larger scores for Health Concerns $(z=-4.2, p=1 \mathrm{e}-06)$.

The dimensions of Verbal Thoughts and Theory of Mind were significantly different between males and females. During the resting-state session, women reported a greater frequency of Verbal Thoughts $(z=-2.96, p=0.003)$ and Theory of Mind $(z=-2.2, p=0.02)$.

The mixed effect of Group and Gender showed that Discontinuity of Mind was significantly higher in female participants in the fMRI group and male participants in the EEG group: $\mathrm{F}(1,2013)=8.0019, p=0.005$ (Figure 3 ). 
Figure 3

Mixed-Effect of Group and Gender for the ARSQ Dimension of Discontinuity of Mind

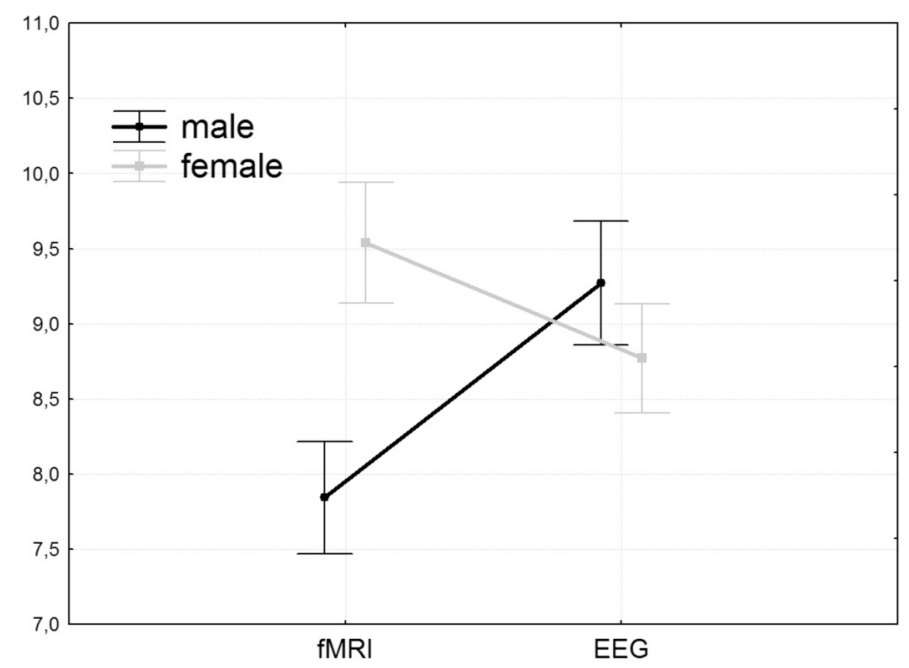

Ten-Factor Model of Russian ARSQ 2.0

The confirmatory factor analyses showed that, consistent with previous data (Diaz et al., 2014, p. 271), the sample data fit the 10-factor structure. Goodness of fit was estimated as $\left.\chi^{2}(360, \mathrm{~N}=217)=2571.264\right)$, root-mean-square error of approximation (RMSEA) as 0.082, and comparative fit index (CFI) as 0.97. Multigroup confirmatory factorial analysis supported the hypothesis of invariance from the experimental paradigm to the 10-factor ARSQ structure. The resulting $95 \%$ confidence intervals were satisfactory for both CFI $(0.89,0.92)$ and RMSEA $(0.085,0.084)$ for the EEG and fMRI groups separately and combined.

Moreover, confirmatory factor analysis confirmed the high correspondence of items to the factors both in fMRI and EEG group (Table 1).

\section{Discussion}

Between-factor correlation coefficients manifested similar features in the present sample as in the initially reported results (Diaz et al., 2014). Specifically, similar positive correlations were found between Discontinuity of Mind and Planning and, in the fMRI group, similar negative correlations between Comfort and Health Concerns.

Nevertheless, there were also differences in the correlation of factors. In Diaz et al.'s (2014) study, the Comfort dimension was inversely correlated with Discontinuity of Mind and Theory of Mind among Dutch-speaking respondents, indicating that a state of discomfort accompanied thoughts about others and difficulty restraining a particular thought or thoughts. In contrast, data obtained from 
Table 1

Descriptive Statistics of Amsterdam Resting-State Questionnaire (ARSQ) Items and Factors. $\mathrm{C} \alpha-$ Cronbach's $\alpha$ designates reliability of factor items

\begin{tabular}{|c|c|c|c|c|c|c|c|c|c|c|}
\hline \multicolumn{11}{|c|}{ Standardized factor loading (Mean \pm SD. C $\alpha$ ) } \\
\hline Factors: & 1 & 2 & 3 & 4 & 5 & 6 & 7 & 8 & 9 & 10 \\
\hline & \multicolumn{10}{|c|}{ EEG group } \\
\hline Items: & 0.73 & 0.74 & 0.65 & 0.82 & 0.75 & 0.71 & 0.69 & 0.70 & 0.69 & 0.68 \\
\hline 1.1 'I had busy thoughts' & 0.59 & & & & & & & & & \\
\hline 1.2 'I had rapidly switching thoughts' & 0.81 & & & & & & & & & \\
\hline 1.3 'I had dif culty holding on to my thoughts' & 0.78 & & & & & & & & & \\
\hline 2.1 'I thought about others' & & 0.73 & & & & & & & & \\
\hline 2.2 'I thought about people I like' & & 0.85 & & & & & & & & \\
\hline 2.3 'I placed myself in other people's shoes' & & 0.63 & & & & & & & & \\
\hline 3.1 'thought about my feelings' & & & 0.66 & & & & & & & \\
\hline 3.2 'I thought about my behavior' & & & 0.54 & & & & & & & \\
\hline 3.3 'I thought about myself' & & & 0.74 & & & & & & & \\
\hline 4.1 'I thought about things I need to do' & & & & 0.85 & & & & & & \\
\hline 4.2 'I thought about solving problems' & & & & 0.79 & & & & & & \\
\hline 4.3 'I thought about the future' & & & & 0.81 & & & & & & \\
\hline 5.1 'I felt tired' & & & & & 0.76 & & & & & \\
\hline 5.2 'I felt sleepy' & & & & & 0.76 & & & & & \\
\hline 5.3 'I had dif culty staying awake' & & & & & 0.75 & & & & & \\
\hline 6.1 'I felt comfortable' & & & & & & 0.62 & & & & \\
\hline 6.2 'I felt relaxed' & & & & & & 0.71 & & & & \\
\hline 6.3 'I felt happy' & & & & & & 0.79 & & & & \\
\hline 7.1 'I was conscious of my body' & & & & & & & 0.57 & & & \\
\hline 7.2 'I thought about my heartbeat' & & & & & & & 0.67 & & & \\
\hline 7.3 'I thought about my breathing' & & & & & & & 0.82 & & & \\
\hline 8.1 'I felt ill' & & & & & & & & 0.59 & & \\
\hline 8.2 'I thought about my health' & & & & & & & & 0.93 & & \\
\hline 8.3 'I felt pain' & & & & & & & & 0.58 & & \\
\hline 9.1 'I thought in images' & & & & & & & & & 0.63 & \\
\hline 9.2 'I pictured events' & & & & & & & & & 0.73 & \\
\hline 9.3 'I pictured places' & & & & & & & & & 0.71 & \\
\hline 10.1 'I thought in words' & & & & & & & & & & 0.78 \\
\hline 10.2 'I had silent conversations' & & & & & & & & & & 0.73 \\
\hline 10.3 'I imagined talking to myself' & & & & & & & & & & 0.54 \\
\hline
\end{tabular}


Table 1 (finishing)

\begin{tabular}{|c|c|c|c|c|c|c|c|c|c|c|}
\hline Factors: & 1 & 2 & 3 & 4 & 5 & 6 & 7 & 8 & 9 & 10 \\
\hline & \multicolumn{10}{|c|}{ fMRI group } \\
\hline Items: & 0.75 & 0.81 & 0.80 & 0.87 & 0.79 & 0.75 & 0.69 & 0.65 & 0.84 & 0.82 \\
\hline 1.1 'I had busy thoughts' & 0.64 & & & & & & & & & \\
\hline 1.2 'I had rapidly switching thoughts' & 0.89 & & & & & & & & & \\
\hline 1.3 'I had dif culty holding on to my thoughts' & 0.72 & & & & & & & & & \\
\hline 2.1 'I thought about others' & & 0.95 & & & & & & & & \\
\hline 2.2 'I thought about people I like' & & 0.93 & & & & & & & & \\
\hline 2.3 'I placed myself in other people's shoes' & & 0.54 & & & & & & & & \\
\hline 3.1 'thought about my feelings' & & & 0.81 & & & & & & & \\
\hline 3.2 'I thought about my behavior' & & & 0.75 & & & & & & & \\
\hline 3.3 'I thought about myself' & & & 0.84 & & & & & & & \\
\hline 4.1 'I thought about things I need to do' & & & & 0.89 & & & & & & \\
\hline 4.2 'I thought about solving problems' & & & & 0.85 & & & & & & \\
\hline 4.3 'I thought about the future' & & & & 0.87 & & & & & & \\
\hline 5.1 'I felt tired' & & & & & 0.57 & & & & & \\
\hline 5.2 'I felt sleepy' & & & & & 0.92 & & & & & \\
\hline 5.3 'I had dif culty staying awake' & & & & & 0.89 & & & & & \\
\hline 6.1 'I felt comfortable' & & & & & & 0.80 & & & & \\
\hline 6.2 'I felt relaxed' & & & & & & 0.85 & & & & \\
\hline 6.3 'I felt happy' & & & & & & 0.59 & & & & \\
\hline 7.1 'I was conscious of my body' & & & & & & & 0.71 & & & \\
\hline 7.2 'I thought about my heartbeat' & & & & & & & 0.61 & & & \\
\hline 7.3 'I thought about my breathing' & & & & & & & 0.76 & & & \\
\hline 8.1 'I felt ill' & & & & & & & & 0.59 & & \\
\hline 8.2 'I thought about my health' & & & & & & & & 0.76 & & \\
\hline 8.3 'I felt pain' & & & & & & & & 0.61 & & \\
\hline 9.1 'I thought in images' & & & & & & & & & 0.83 & \\
\hline 9.2 'I pictured events' & & & & & & & & & 0.83 & \\
\hline 9.3 'I pictured places' & & & & & & & & & 0.85 & \\
\hline 10.1 'I thought in words' & & & & & & & & & & 0.89 \\
\hline 10.2 'I had silent conversations' & & & & & & & & & & 0.89 \\
\hline 10.3 'I imagined talking to myself' & & & & & & & & & & 0.68 \\
\hline
\end{tabular}

Note. Questionnaire factors: (1) Discontinuity of Mind, (2) Theory of Mind, (3) Self, (4) Planning, (5) Sleepiness, (6) Comfort, (7) Somatic Awareness, (8) Health Concerns, (9) Visual Thought, and (10) Verbal Thought. 
Russian-speaking respondents revealed a positive relationship between Comfort and Discontinuity of Mind as well as between Comfort and Theory of Mind.

One possible explanation for this difference is that participants in the initial ARSQ 2.0 approbation were recruited from the Dutch Sleep Registry Database (www.sleepregistry.org/) and may thus have had concerns about their quality of sleep before beginning the study. Importantly, more recent studies of insomnia have revealed a relationship between sleep disorders and high scores for Discontinuity of Mind (Palagini et al., 2016).

When we compared respondent data obtained from two different experimental conditions (fMRI- and EEG-recording sessions), we found the following differences in the ARSQ dimension scores: higher Theory of Mind, Sleepiness, and Comfort values for the EEG group and higher Health Concerns values for the fMRI group. The ratings of Sleepiness and Health Concerns might be unstable (Diaz et al., 2014) due to their dependence on external factors (McKiernan, D'Angelo, Kaufman, \& Binder, 2006).

We suspect that the experimental conditions may have influenced these ratings. The fMRI group may have reported lower Comfort and greater Health Concerns than the EEG group due to the stressful nature of MRI scanning, which requires volunteers to stay still in a constrained space. Consistent with this assumption, increased levels of anxiety during MRI scanning have previously been reported (van Minde, Klaming, \& Weda, 2014). Supporting previous results (Diaz et al., 2014), we observed a negative correlation between Health Concern and Comfort. In our EEG group scores for Comfort were higher than in the fMRI group that could also be related to the experimental conditions of EEG and fMRI studies Gusnard, Raichle \& Raichle, 2001; He, Yang, Wilke, \& Yuan, 2011).

The present study also found gender differences for the Verbal Thought dimension of the ARSQ 2.0. Female respondents were more prone to verbal thinking during the resting-state session. The same phenomenon was also observed in Diaz et al.'s (2014) study. Other researchers have consistently emphasized this gender feature. Women, in general, tend to express their thoughts in words and are more successful at performing verbal tasks than men (Hyde, 2005; Mittal, Verma, Jain, Khatter, \& Juyal, 2012), even in early childhood (Buitink, 2017).

In conclusion, our results indicate that the experimental environment may affect the self-reported rating of subjective experience during rest. The fMRI and EEG groups demonstrated differences in ARSQ scores. The fMRI participants felt less comfortable and reported a higher rating of health concerns during fMRI resting-state session. We suggest that the Russian ARSQ can potentially be used in future studies of mind wandering using both EEG and fMRI if the mediating effect of the experimental conditions is taken into account.

\section{Conflict of Interest}

The authors declare that the research was conducted in the absence of any commercial or financial relationship that could be construed as a potential conflict of interest. 


\section{Author contributions}

GP, AT, KL, AI and OM conceived of and designed the study; GP, AT, and KL collected data; GP, AT and KL analyzed the data; and GP and OM wrote the manuscript.

\section{Acknowledgments}

We gratefully acknowledge the developers of the ARSQ (principally, Dr. Linkenkaer-Hansen) for providing us with all testing materials required for this study.

\section{References}

Aldao, A., Nolen-Hoeksema, S., \& Schweizer, S. (2010). Emotion-regulation strategies across psychopathology: A meta-analytic review. Clinical Psychology Review, 30(2), 217-237. doi:10.1016/j.cpr.2009.11.004

Benjamini, Y., \& Hochberg, Y. (1995). Controlling the false discovery rate: a practical and powerful approach to multiple testing. Journal of the Royal Statistical Society. Series B (Methodological), 57(1), 289-300.

Birn, R. M., Molloy, E. K., Patriat, R., Parker, T., Meier, T. B., Kirk, G. R., ... Prabhakaran, V. (2013). The effect of scan length on the reliability of resting-state fMRI connectivity estimates. NeuroImage, 83, 550-558.

Buitink, M. (2017). A gender-comparison between verbal and figural divergent thinking in 4-year-old children, using the Torrance Test of Creative Thinking and the Alternative Uses Task (Master thesis). Retrieved from Utrecht University Repository.

Cantero, J. L., Atienza, M., \& Salas, R. M. (2002). Human alpha oscillations in wakefulness, drowsiness period, and REM sleep: different electroencephalographic phenomena within the alpha band. Neurophysiologie Clinique/Clinical Neurophysiology, 32(1), 54-71.

Damoiseaux, J. S., Rombouts, S. A. R. B., Barkhof, F., Scheltens, P., Stam, C. J., Smith, S. M., \& Beckmann, C. F. (2006). Consistent resting-state networks across healthy subjects. Proceedings of the National Academy of Sciences of the United States of America, 103(37), 13848-13853. doi:10.1073/pnas.0601417103

Diaz, B. A., Hardstone, R., Mansvelder, H. D., van Someren, E. J., \& Linkenkaer-Hansen, K. (2016). Resting-state subjective experience and EEG biomarkers are associated with sleep-onset latency. Frontiers in Psychology, 7, 492. doi:10.3389/fpsyg.2016.00492

Diaz, B. A., van der Sluis, S., Benjamins, J. S., Stoffers, D., Hardstone, R., Mansvelder, H. D., ... Linkenkaer-Hansen, K. (2014). The ARSQ 2.0 reveals age and personality effects on mind-wandering experiences. Frontiers in Psychology, 5, 271. doi:10.3389/fpsyg.2014.00271

Diaz, B.A., van der Sluis, S., Moens, S., Benjamins, J. S., Migliorati, F., Stoffers, D., ... LinkenkaerHansen, K. (2013). The Amsterdam Resting-State Questionnaire reveals multiple phenotypes of resting-state cognition. Frontiers in Human Neuroscience, 7, 446. doi:10.3389/fnhum.2013.00446

Fenigstein, A. (1987). On the nature of public and private self-consciousness. Journal of Personality, 55(3), 543-554. doi:10.1111/j.1467-6494.1987.tb00450.x 
Fox, M. D., Snyder, A. Z., Vincent, J. L., Corbetta, M., Van Essen, D. C., \& Raichle, M. E. (2005). The human brain is intrinsically organized into dynamic, anticorrelated functional networks. Proceedings of the National Academy of Sciences of the United States of America, 102(27), 96739678. doi:10.1073/pnas.0504136102

Glover, G. H. (2011). Overview of functional magnetic resonance imaging. Neurosurgery Clinics of North America, 22(2), 133-139, vii. doi:10.1016/j.nec.2010.11.001

Gorgolewski, K. J., Lurie, D., Urchs, S., Kipping, J. A., Craddock, R. C., Milham, M. P., ... Smallwood, J. (2014). A correspondence between individual differences in the brain's intrinsic functional architecture and the content and form of self-generated thoughts. PLoS ONE, 9(5), e97176. doi:10.1371/journal.pone.0097176

Gusnard, D. A., Raichle, M. E., \& Raichle, M. E. (2001). Searching for a baseline: functional imaging and the resting human brain. Nature Reviewes Neuroscience, 2(10), 685-694. doi:10.1038/35094500

He, B., Yang, L., Wilke, C., \& Yuan, H. (2011). Electrophysiological imaging of brain activity and connectivity-challenges and opportunities. IEEE Transactions on Biomedical Engineering, 58(7), 19181931. doi:10.1109/tbme.2011.2139210

Heine, L., Soddu, A., Gomez, F., Vanhaudenhuyse, A., Tshibanda, L., Thonnard, M., ... Demertzi, A. (2012). Resting state networks and consciousness: alterations of multiple resting state network connectivity in physiological, pharmacological, and pathological consciousness states. Frontiers in Psychology, 3, 295. doi:10.3389/fpsyg.2012.00295

Hyde, J. S. (2005). The gender similarities hypothesis. The American Psychologist, 60(6), 581-592. doi:10.1037/0003-066x.60.6.581

James, W. (1890). The principles of psychology. New York: H. Holt.

Killingsworth, M. A., \& Gilbert, D. T. (2010). A wandering mind is an unhappy mind. Science, 330(6006), 932. doi:10.1126/science.1192439

Krug, K., Salzman, C. D., \& Waddell, S. (2015). Understanding the brain by controlling neural activity. Philosophical Transactions of the Royal Society B. Biological Sciences, 370(1677), 20140201. doi:10.1098/rstb.2014.0201

Lee, M. H., Smyser, C. D., \& Shimony, J. S. (2013). Resting-state fMRI: a review of methods and clinical applications. American Journal of Neuroradiology, 34(10), 1866-1872. doi:10.3174/ajnr.A3263

Mantini, D., Perrucci, M. G., Del Gratta, C., Romani, G. L., \& Corbetta, M. (2007). Electrophysiological signatures of resting state networks in the human brain. Proceedings of the National Academy of Sciences of the United States of America, 104(32), 13170-13175. doi:10.1073/pnas.0700668104

Matthews, G., Campbell, S. E., Falconer, S., Joyner, L. A., Huggins, J., Gilliland, K., ... Warm, J. S. (2002). Fundamental dimensions of subjective state in performance settings: task engagement, distress, and worry. Emotion, 2(4), 315-340. doi:10.1037/1528-3542.2.4.315

McKiernan, K. A., D'Angelo, B. R., Kaufman, J. N., \& Binder, J. R. (2006). Interrupting the "stream of consciousness": an fMRI investigation. NeuroImage, 29(4), 1185-1191. doi:10.1016/j.neuroimage.2005.09.030

Mittal, S., Verma, P., Jain, N., Khatter, S., \& Juyal, A. (2012). Gender based variation in cognitive functions in adolescent subjects. Annals of Neurosciences, 19(4), 165-168. doi:10.5214/ans.0972.7531.190406

Palagini, L., Cellini, N., Mauri, M., Mazzei, I., Simpraga, S., dell’Osso, L., ... Riemann, D. (2016). Multiple phenotypes of resting-state cognition are altered in insomnia disorder. Sleep Health, 2(3), 239-245. doi:10.1016/j.sleh.2016.05.003 
Portnova, G. V., Tetereva, A., Balaev, V., Atanov, M., Skiteva, L., Ushakov, V., ... Martynova, O. (2018). Correlation of BOLD signal with linear and nonlinear patterns of EEG in resting state EEGinformed fMRI. Frontiers in Human Neuroscience, 11, 654. doi:10.3389/fnhum.2017.00654

Raichle, M. E., MacLeod, A. M., Snyder, A. Z., Powers, W. J., Gusnard, D. A., \& Shulman, G. L. (2001). A default mode of brain function. Proceedings of the National Academy of Sciences of the United States of America, 98(2), 676-682. doi:10.1073/pnas.98.2.676

Sojoudi, A., \& Goodyear, B. G. (2016). Statistical inference of dynamic resting-state functional connectivity using hierarchical observation modeling. Human Brain Mapping, 37(12), 4566-4580. doi:10.1002/hbm.23329

Stoffers, D., Diaz, B. A., Chen, G., den Braber, A., van 't Ent, D., Boomsma, D. I., ... Linkenkaer-Hansen, K. (2015). Resting-State fMRI functional connectivity is associated with sleepiness, imagery, and discontinuity of mind. PLoS ONE, 10(11), e0142014. doi:10.1371/journal.pone.0142014

Van Dijk, K. R., Hedden, T., Venkataraman, A., Evans, K. C., Lazar, S. W., \& Buckner, R. L. (2010). Intrinsic functional connectivity as a tool for human connectomics: theory, properties, and optimization. Journal of Neurophysiology, 103(1), 297-321. doi:10.1152/jn.00783.2009

Van Minde, D., Klaming, L., \& Weda, H. (2014). Pinpointing moments of high anxiety during an MRI examination. International Journal of Behavioral Medicine, 21(3), 487-495. doi:10.1007/s12529-013-9339-5

Galina V. Portnova - Senior Research Fellow, Human Higher Nervous Activity Lab, Institute of Higher Nervous Activity and Neurophysiology of the Russian Academy of Sciences, PhD, MD. Research Area: brain activity of different groups of patients (schizophrenia, autistic spectrum disorder, patients in coma or vegetative state, patients after stroke or with chronic ischemia), cognitive and emotional processes during development and aging, consciousness process including resting-states.

Email: caviter@list.ru

Alina O. Tetereva - Junior Research Fellow, Laboratory of Human Higher Nervous Activity, Institute of Higher Nervous Activity and Neurophysiology of the Russian Academy of Sciences; Research Assistant, Centre for Cognition and Decision Making, National Research University Higher School of Economics, MSc.

Research Area: fMRI correlates of human cognitive functions.

Email: alina.tao@mail.ru

Alexey M. Ivanitsky - Professor, MD, PhD, Institute of Higher Nervous Activity and Neurophysiology of the Russian Academy of Sciences.

Research Area: human brain physiology, brain base of human mind and consciousness.

Email: alivanit@aha.ru

Olga V. Martynova - Head of the Laboratory of Human Higher Nervous Activity, Institute of Higher Nervous Activity and Neurophysiology of the Russian Academy of Sciences; Senior Scientist, Centre for Cognition and Decision Making, National Research University Higher School of Economics, PhD.

Research Area: EEG and fMRI correlates of human cognitive functions.

Email: olmart@mail.ru, omartynova@hse.ru

Krystsina M. Liaukovich - PhD student, Human Higher Nervous Activity Lab, Institute of Higher Nervous Activity and Neurophysiology of the Russian Academy of Sciences, MSc.

Research Area: sleep, consciousness, EEG, and cognitive ERPs. The scientific interest is in the process of the level of consciousness recovery after awakening from different phases and stages of sleep. Email: krystsina.liaukovich@gmail.com 


\title{
Влияние экспериментальных условий, размера выборки и продолжительности исследования на субъективные ощущения в состоянии покоя
}

\author{
Г.В. Портнова ${ }^{a}$, А.О. Тетерева ${ }^{\text {a,b }}$, А.М. Иваницкий ${ }^{a}$, О.В. Мартынова ${ }^{a, b}$, К.М. Левкович ${ }^{a}$ \\ ${ }^{a}$ Институт высшей нервной деятельности и нейрофизиологии Российской академии наук, 117485, \\ Россия, Москва, ул. Бутлерова, д. 5 а \\ ${ }^{b}$ Национальный исследовательский университет «Высшая школа экономики», 101000, Россия, \\ Москва, ул. Мясницккал, д. 20
}

\section{Резюме}

Статья посвящена изучению особенностей состояний покоя в условиях регистрации электроэнцефалограммы (ЭЭГ) и функциональной магниторезонансной томографии (фМРТ), каждое из которых имеет свою специфику. С этой целью были проведены максимально приближенные друг к другу по экспериментальным условиям фМРТ- и ЭЭГисследования, в которых 108 и 109 здоровых добровольцев соответственно в течение 10 минут находились в состоянии спокойного бодрствования во время проведения данных процедур. Субъективное содержание сознания в состоянии покоя у испытуемых оценивалось при помощи опросника Amsterdam Resting-State Questionnaire (ARSQ) 2.0. Для подтверждения 10-факторной структуры опросника в обеих группах испытуемых был применен метод конфирматорного факторного анализа, межгрупповые различия оценивались при помощи теста Манна-Уитни. Было выявлено, что в целом ответы на вопросы опросника Amsterdam Resting-State Questionnaire 2.0. в обеих группах испытуемых были схожими. Однако в состоянии покоя при ЭЭГ-исследовании испытуемые чаще выбирали ответы, соответствующие состояниям Комфорта, Сонливости и Визуального мышления, тогда как участники фМРТ-исследования сообщали о более частых мыслях, связанных с беспокойством о собственном здоровье. Кроме того, в обеих экспериментальных группах были обнаружены гендерные различия, проявляющиеся в большей активности вербального мышления у женщин в состоянии покоя. Таким образом, было выявлено, что мысли и ощущения испытуемых, не выполняющих никаких заданий и находящихся в состоянии покоя, зависят от применяемых методов исследования даже при максимально схожих экспериментальных условиях, что следует учитывать при планировании исследования и анализе данных.

Ключевые слова: Амстердамский опросник состояний покоя, состояния покоя, фМРТ, ЭЭГ, мыслительная активность.

Портнова Галина Владимировна - старший научный сотрудник, лаборатория высшей нервной деятельности человека, Институт высшей нервной деятельности и нейрофизиологии Российской академии наук, кандидат биологических наук, невролог, врач функциональной диагностики.

Сфера научных интересов: клинические особенности работы мозга при различных видах психической и неврологической патологии, когнитивные эмоциональные процессы, исследование осознаваемых и неосознаваемых процессов при помощи методов ЭЭГ и функционального МРТ.

Контакты: caviter@list.ru 
Тетерева Алина Олеговна - младший научный сотрудник, лаборатория высшей нервной деятельности человека, Институт высшей нервной деятельности и нейрофизиологии; стажер-исследователь, Центр нейроэкономики и когнитивных исследований, Национальный исследовательский университет «Высшая школа экономики».

Сфера научных интересов: фМРТ когнитивных функций человека.

Контакты: alina.tao@mail.ru

Иваницкий Алексей Михайлович - советник РАН, Институт высшей нервной деятельности и нейрофизиологии Российской академии наук, чл.-корр. РАН, профессор, доктор медицинских наук.

Сфера научных интересов: физиологические основы психики и сознания человека.

Контакты: alivanit@aha.ru

Мартынова Ольга Владимировна - заведующая лабораторией высшей нервной деятельности человека, Институт высшей нервной деятельности и нейрофизиологии Российской академии наук; старший научный сотрудник, Центр нейроэкономики и когнитивных исследований, Национальный исследовательский университет «Высшая школа экономики», $\mathrm{PhD}$.

Сфера научных интересов: ЭЭГ и фМРТ когнитивных функций человека.

Контакты: olmart@mail.ru, omartynova@hse.ru

Левкович Кристина Михайловна - аспирант, Институт высшей нервной деятельности и нейрофизиологии Российской академии наук.

Сфера интересов: сон, сознание, ЭЭГ, когнитивные вызванные потенциалы.

Контакты: krystsina.liaukovich@gmail.com 